\title{
Tourismmorphosis : Badung, Banyuwangi and Luwu Timur Regency (Tourism Evolution Analysis)
}

\author{
I Gusti Agung Oka Mahagangga ${ }^{1}$, I Putu Anom², I Made Kusuma Negara ${ }^{3}$ \\ Faculty of Tourism, Udayana University \\ Email: okamahangga@unud.ac.id ${ }^{1}$
}

\begin{abstract}
Tourismmorphosis in Badung regency, Banyuwangi regency and Luwu Timur regency is field research to understanding developing of tourism as tourism evolution analysis. Tourismmorphosis analyzed was postmodern evolution approach with case study and qualitative methods to find tourism developing stages. Begin from the introduction stage, reaction stage, institutionalization stage and compromise stage. The research novelty described that Badung Regency having reached the compromise stage, Banyuwangi Regency reached the institutionalization stage and Luwu Timur regency just started to the introductory stage. The prediction of tourism development future in Badung regency will permanent at the compromise stage, Banyuwangi Regency stay at the institutionalization stage, and Luwu Timur district will enter the reaction stage within ten until fifteen years letters.
\end{abstract}

Keywords: Tourism, Evolution Tourismmorphosis, Developing

\section{INTRODUCTION}

Tourism in Indonesia has developed more than a hundred years. But still hard to find developing as evolution research of tourism. This article examines the evolutions of tourism in Badung regency that assumed have advanced progressed, Banyuwangi regency assumed in the process of developing position and Luwu Timur regency that assumed in embryotic position. With great expectation, the result of this research could be use with the expert, stakeholders, the central government, local governments, tourism practitioners and local people. Especially for policies and decisions in planning tourism development to the future.

This article has been built as tourismmorphosis in Badung, Banyuwangi and Luwu Timur based on field research and literature study. Referring to Anom (et al., 2017) who was inspired by Noronha has studied about the impact of tourism (1977, 1979; Cohen, 1979, 1984; Raharjo and Munandar, 1998). Anom (et al., 2017) found the tourismmorphosis concept as an analysis model of tourism evolution or development (but using a different approach to Butler (1980) which is often used for tourism development).Tourismorphosis has consisting of four stages. The first stage is introduction for tourism, second stage is reaction, the third stage is institutionalization and the last stage is compromise. So, Tourismorphosis as some kind evolution model to analyzing and discussed tourism development from discourses, paradigms, actors and supporting institutionalization each stage at each regency. Emic approach and ethical approach was tried to practiced with careful and balanced in this research.

\section{MATERIALS AND METHOD}

In this article used systematicly concepts and theories to guide researchers blueprint. The main theory is genealogy theory as discourse, paradigm, discourse, actor, and supporting institutionalization (Foucoult, 1954, in Arif, 2014), critical evolutionism approach (Wijayanto, 2013), and Tourismmorphosis analysis model (Anom, et al., 2017). This research uses qualitative research methods (Muhadjir, 2002), with primary data sources and secondary data with qualitative and quantitative typical data (Sugiyono, 2005). Data collection techniques with observation techniques, in-depth interview techniques, and literature studies (Bungin, 2003; Moleong, 2005; Sugiyono, 2005). The technique of determining informants using purposive sampling (Sugiyono, 2005). Data analysis techniques used qualitative data analysis (Miles and Huberman, 1992) and data 
interpretation using hermeneutical techniques (Sugiharto, 1996).

\section{RESULTS}

When realized, its so difficult to create understanding the development or evolution as tourismmorphosis in the three regency. Many facts, information, data, event, incident and phenomenon, must be clarified and analyzed. Historical approached, socio-cultural, development economic and political approached used to find the truth. Reference to qualitative methodology, the researchers tried to compile all data with the fact of observation than interpretate as hermeneutics.

Tourismmorphosis in Badung regency showed that the tourism development cannot be separated from the role of the Dutch colonial government, foreign artists-social-cultural scientist, the central government, local governments, entrepreneurs who have networks in the center and global networking companies, beside local people roles. Begin from the introductory stage (1912-1919), the reaction stage (1930-1938), institutionalization stage I (1950-1968), institutionalization stage II (1969-1990), institutionalization stage III (1991-2011) and the 2012 compromise stage until now.

The introductory stages I (1805-1930) of tourismmorphosis in Banyuwangi regency began with slow development for the tourism sector. Because the colonial government at that time focused at plantation and port area for the international trade sector. The introductory stage II (1950-2000) also has a fairly long span of time. Based on the geneology of Banyuwangi regency, did not has "tourism spirit", although many unique tourist attractions have been introduced by foreigners especially French at this stage (Kawah Ijen, Plengkung Beach and the others). The uniqueness of local culture has been revitalized but is still limited to people's entertainment (gandrung and the others). The reaction stages (2001-2009) was shown by the figure of the Regent Samsul Hadi establishing a local cultural identity politics and starting to open potential tourism objects. This effort was continued by Regent Abdullah Azwar Anas who was genius capable of planning and developing tourism as an "umbrella development sector in Banyuwangi regency" at the stage of institutionalization (2010-present). At this institutionalization stage Regent Abdullah Azwar Anas have influence the spirit of tourism in Banyuwangi regency with powerfull support from the central goverment. Based on statistical data, the number of domestic tourist visits jumped sharply. Economic growth in Banyuwangi regency grew rapidly and was claimed because of the successful development of the tourism sector with branding strategies. Dozens of domestic and foreign awards, including from the United Nations, were won by Banyuwangi regency under the leadership of regent Abdullah Azwar Anas.

In Luwu Timur, the development of the tourism sector in Luwu Timur district in development planning starts from zero in the sense of trying to format tourism as what will be made. This means that in addition to not yet having a tourism regulations, regional income sources cannot be obtained (except in Sorowako which has developed rental, lodging and hotels after the establishment of the largest Nickel mining in Indonesia starting in the 1980s). So the desire to develop the tourism sector in Luwu Timur district is actually very speculative and risky when viewed from the economics perspective.

\section{DISCUSSIONS}

However, it seems appropriate the assumption in background that Badung regency has advanced progressed, Banyuwangi regency in the process of developing position and Luwu Timur regency in embryotic position. Tourismmorphosis model analysis show Badung regency at the compromise stage (stage 4/compromise of tourismmorphosis), Banyuwangi regency at the institutionalization stage (stage 3/of institutionalization tourismmorphosis) and Luwu Timur regency at the Introduction stage (stage 1 / introduction of tourismmorphosis). As can be seen in the following picture :

Picture 1. Tourismmorphosis in Badung, Banyuwangi and Luwu Timur

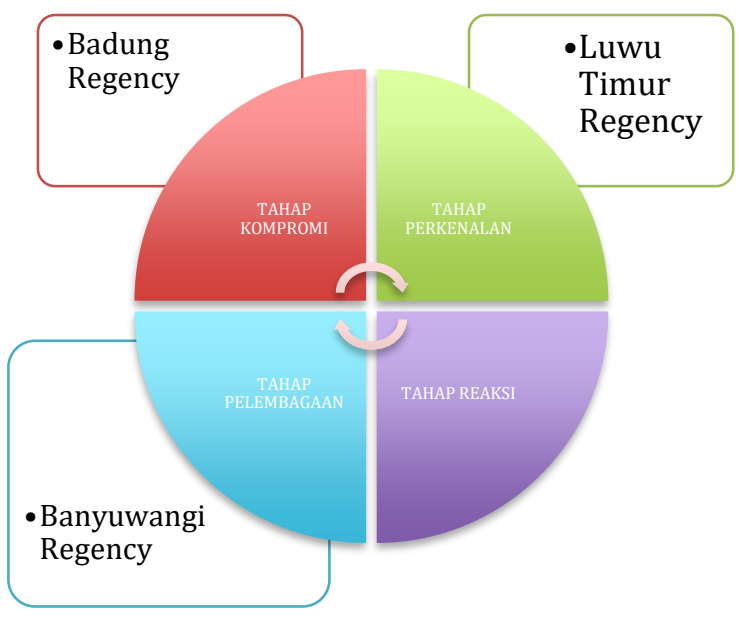

Seeing the tourismmorphosis at picture 1 above, Badung regency position in the stage of compromise as a final stages with a whole series of complex developments. The next prediction of Badung regency will be adaptated to the future dimensions of tourism. The compromise stage emphasizes like "anything can be done for tourism" in the positive sense that tourism has a central role in 
all aspects of development. At the stage of compromise if tourism encounters major obstacles or obstacles it will undermine the joints of other development sectors and reveal to all aspects of the life of the Badung society. In the future, The dependence on tourism in Badung regency is not just an assumption, hypothesis or conjecture but a reality that must be understood for the sustainability of the tourism sector and the welfare of the people of Badung.

Banyuwangi regency is in the institutionalization stage position of tourismmorphosis. Which signifies its development is giving birth to many supporting institutionalization for strengthening the tourism sector. Institutionalization structure and social functions depend on internal factors and external factors. Fast action and reaction are important in managing the tourism sector at the institutionalization stage. When institutionalization is strong in several dimensions of tourism, Banyuwangi regency can get ready for the stage of compromise. If this happens it means that other sectors have "failed to compete" and the tourism sector has become the only major sector in development. Depending on the figures, the actors will determine politically and the local community may be faced with dilemmatic choices. Therefore, it is possible that Banyuwangi regency remained stagnant at the institutionalization stage in tourism. It doesn't matter because Banyuwangi regency has significant sectors such as the agriculture-plantationfisheries-mining sector from along ago. There is a possibility of a decline in the tourismmorphosis stage back to the reaction stage because of the sharp differences of opinion between new actors and the community elite or with the community, competition between tourism components that require reidentification / re-formulation of the tourism sector, a decrease in tourist visits or causes others. Unless the next leader has the same quality and quantity as the regent Abdullah Azwar Anas and support from the central government is also not different, then tourism development in Banyuwangi will soon reach the stage of compromise.

The Luwu Timur regency do not do tourism sector development scheme before. Tourismmorphosis model analysis show Luwu Timur regency at the introductory stage. But they have many tourism potentials lika nature and culture. Supported that local people have high needs to leisure and recreation, include people around Luwu Timur regency. Although foreign tourists arriving is small intensity but many tourist come for transit to go to Palu or North Sulawesi. Beside, the younger generation start showing excited and active to involve in tourism activities. Thus phenomenon appears good or promising prospect in the future, especially if the local government can plaining and developing for the future (include to make specific rules about tourism / Peraturan Daerah-Perda Pariwisata).

In three years, begin from 2016 tourism development at Luwu Timur still focused on infrastructure. About promotion and marketing that has not been carried yet. But it can be ascertained that in 5 years, if the regional government continues to focus on the development of the tourism sector, Luwu Timur regency will enter the reaction phase of tourism policies (especially if accessibility such as an airport can be realized and PT Vale's CSR for tourism sector development can be achieved).

The focus of tourism development is suggested to be natural potential and artificial potential. Although Luwu Timur has acknowledged to have many cultural potential, its look difficult to quickly pack it. Unless it has started from now on revitalization and preservation of diverse local cultures (Proto Melayu: Padoe people, Toraja people and Pamona people are mostly in the mountains. Deutro Melayu: Bugis people mostly in coastal areas with the great epic Ilagaligo-Sawerigading).

\section{CONCLUSIONS}

Based on tourismmorphosis model analysis in Badung Regency, Banyuwangi Regency and Luwu Timur Regency, there is each conclusions were obtained:

1. The development of tourism in Badung regency has been built since the Dutch colonial era as the introductory stage and the reaction stage, followed by the central-local governmentprivate-community at the stage of institutionalization and regional governmentlocal government-network of global-privatecommunity corporations in stage of compromise. The role of the Dutch colonial government, the central government and its networks (large national corporations) and global corporate networks have a strong power in tourism development. Until now, all the leader of Badung local goverment are in comfort zone but always to keep economic growth highly. The final institutionalization stage and the compromise stage provide opportunities for local governments for development programs related to locality but still dominate the ownership of capital that always has a relationship with the central government has a significant role. Tourism development is very rapid and is indicated to be heading towards the North Badung region massively. On the other hand tradition, adat and religiosity in the frame of the desa pekraman / desa adat are increasingly solid. Badung have complex tourism problems in compromise stages, but all the problems seen accommodated to be compromised with win-win solution. The paradigm tourism development in 
Badung at compromise stages is transturism, which is a complex tourism problem and various interests, is accommodated to be compromised as a way to find win-win solution cause economic factors.

2. The development of tourism in Banyuwangi regency shows that the introductory stage is more supported by foreigners (researchers in Ijen) and foreign surfers (Plengkung beach) who indirectly promote these 2 locations in to the world in the form of television books, documentaries and sport even. The reaction stage with the otonomi daerah era (but after the economic crisis and Bali bomb I) has been shown tourism development through tourism identity. Until the research ended, it showed that Banyuwangi was at the stage of institutionalization with the strength of the leadership of Regent Abdullah Azwar Anas with integrated development concepts with tourism as his umbrella had shown brilliant results. Branding tourism is the mainstay of tourism development by compiling all sectors in festivals, events, carnivals as a tourism commodity-culture product. The strongest potential for tourists is natural potential. While the potential of artificial cultures is still in demand by domestic tourists and local visitors. MICE is the prospect of Banyuwangi district tourism development in the future (supported by natural potential and cultural potential). Therefore, the paradigm tourism development in Banyuwangi regency at institutionalization stages is integrated development.

3. The development of tourism in Luwu Timur regency, is still at the introduction stage since 1969-present. Until 2016, Luwu Timur never interested in tourism sector development yet. Even though there are foreign tourist transit locations in Mangkutana, pantai Lemo and natural tourism opportunities in Lake Matano since the 1990s. In 2016 has begun tourism planned, in 2017 the determination of priority scale and 2018 is focused on structuring infrastructure in priority tourist attractions. In 2019-2021 the focus was on promotions and targeting the market share of foreign tourists. The paradigm of tourism development in Luwu Timur regency is developmentism.

\section{ACKNOWLEDGEMENT}

We greatly appreciate to the minister of research and technology RI, Rector Udayana University, Chief Udayana University Research Centre, Badung Government, Banyuwangi Government and Luwu Timur Goverment for support to our research.We also want to express special thanks to contributed people about the discussed topics.

\section{REFERENCES}

[ 1 ] Anom, I. P., Suryasih, I. A., Nugroho, S., \& Mahagangga, I. G. A. O. 2017. Turismemorfosis: Tahapan selama seratus tahun perkembangan dan prediksi pariwisata Bali. Journal of Bali Studies, 7(2), 59-80. Google Scholaar Link

[2] Arief. 2009. Pengetahuan dan Metode: Karya-karya Penting Michel Foucault. : Jalasutra, Yogyakarta

[ 3 ] Bungin, Burhan. 2003. Metodologi Penelitian Kualitatif. Raja Grafindo Persada, Jakarta

[4] Butler, R. W. (1980). The concept of a tourist area cycle of evolution: im- plications for management of resources. Canadian Geographer/ Le Géographe canadien, 24(1), 5-12. Google Scholaar Link.

[ 5 ] Cohen, E. (1979). Rethinking the sociology of tourism. Annals of tourism research, 6(1), 1835. Google Scholaar Link.

[ 6 ] Cohen, E. (1984). The sociology of tourism: approaches, issues, and findings. Annual review of sociology, 10(1), 373-392. Google Scholaar Link.

[ 7 ] Miles, MB dan Huberman, A Michael. 1992. Analisis Data Kualitatif. Universitas Indonesia, Press Jakarta

[ 8 ] Moleong, Lexy. 2005. Metodelogi Penelitian Kualitatif. Remaja Rosda Karya, Bandung.

[ 9] Muhadjir, Noeng. 2000. Metodologi Penelitian Kualitatif. Yogyakarta : Rake Sarasi

[ 10 ] Noronha, R. 1977. Social and cultural dimensions of tourism: A review of the literature in English. Washington DC: World Bank (Draft)

[ 11] Noronha, R. 1979. Paradise reviewed: Tourism in Bali. See de Kadt 1979, pp. 177178

[ 12 ] Raharjo, Supratikno dan Agus Aris Munandar. 1998. "Dampak Pariwisata Terhadap Kebudayaan Bali”. Susanto Zuhdi (ed). Sejarah Kebudayaan Bali : Kajian Pengembangan dan Dampak Pariwisata. Departemen Pendidikan dan Kebudayaan RI, Jakarta 
[13] Sugiharto, Bambang. 1996. Postmodernisme : tantangan bagi filsafat. Kanisius, Yogyakarta

[14] Sugiyono. 2005. Memahami Penelitian Kualitatif. Alfabeta, Bandung

[ 15 ] Wijayanto, E. (2013). Memetika sebagai Studi Kebudayaan Berbasis Evolusi. MELINTAS, 29(1). Google Scholaar Link. 